\title{
The Musical Road of Mr. Wang Lisan
}

\author{
Qing Yu \\ Conservatory of Music, Qingdao University, Qingdao, China, 266071 \\ artyuq@163.com
}

Keywords: composer, music educator, music activist, music creation, contribution

\begin{abstract}
Mr. Wang Lisan, a famous composer, music educator and music social activist in China, was labelled as "the Rightist" in the 1950s and underwent a rough life, but he made great contributions to the creation of piano works, music education and popularization by virtue of his talent and enthusiasm for music.
\end{abstract}

\section{Introduction}

Mr. Wang Lisan, a famous composer, music educator and music social activist in China, devoted his whole life to the creation of piano works. He was labelled as "the Rightist" in the 1950s and underwent a rough life, but he created many unique piano works with distinct nationality and modernity and received lots of awards. Guided by tutor Shen Xuan and Professor Qian Yiping, the author studied for the doctorate at Shanghai Conservatory of Music in 2003 and planned to research the musical road as well as the contributions Mr. Wang Lisan made to music. Unfortunately, Mr. Wang Lisan suffered from stroke when the author prepared to interview him. Therefore, the research was forced to interrupt. Through material collection and dictation from seniors at Shanghai Conservatory of Music, however, the author had a general knowledge of Mr. Wang Lisan' s musical road and the contributions he made to music. Looking back after a dozen years, the author thought that Mr. Wang Lisan' s life and his contributions could still enlighten later generations significantly.

Mr. Wang Lisan, whose ancestral home was Sichuan Province, was born on March 24, 1933, in Wuhan, Hubei Province, and received a good education of both traditional Chinese culture and European music culture when he was young, thus he showed great enthusiasm for traditional Chinese opera, fine arts and other forms of art. He once attempted to compose based on the names of the tunes of Beijing Opera in his boyhood. In 1948, he was enrolled in the Music Department of Sichuan Art School for further study, specializing in piano and violin. The study of this period laid a solid foundation for his later musical road. In the summer of 1951, Mr. Wang Lisan was admitted into the Composition Department of Shanghai Conservatory of Music and learned from such famous experts as Sang Tong, Ding Shande, Chen Mingzhi and Qian Renkang, which laid a solid technological and theoretical foundation for his later music creation.

\section{Music Composer}

Mr. Wang Lisan had begun his career of music creation since the 1950s, covering piano works, orchestral music, vocal music as well as other areas, and his piano works were the best among these areas.

From the year of 1953 to today, Mr. Wang Lisan had created nearly 20 piano works (Wang Lisan Selected Works for the Piano was published by Shanghai Music Publishing House in 2013). These work, though few in number, are different in style and have both full-bodied national customs and strong vitality. Mr. Wang Lisan's works for the piano contained profound cultural foundation and his application of traditional composition techniques improved national culture charm. His notable works Lan Huahua and Artistic Inspiration from Kaii Higashiyama enjoyed a good reputation both at home and abroad and played an important role in the creation and development of piano music in China. What's more, his understanding of music was not only sensitive and unique, but also a real reflection of all eras. The musical contents of his works were profound and away from convention 
because different works had different conceptions. As to application of music techniques, he combined national traditional techniques with western modern composing techniques due to his in-depth study for both traditional Chinese music and the creating techniques of western traditional and modern music. Therefore, his creating technique and style were diversified and his works contained both ethnic music styles and modern western materials.

Mr. Wang Lisan was bold and unconstrained, bright and clear, as well as philosophical and optimistic, and his musical language covered the features of both northern part and southern part of China and integrated western styles into Chinese styles. He developed an imposing, free and easy style of creation, which was unique in the music circle of china, and made significant contributions to the progress of piano music in China.

Lan Huahua, a famous piano work created by Mr. Wang Lisan in 1953, embodied a dramatic plot and had a strong national color. He integrated such emotions as melancholy, indignation, bravery, panic and agitation into this piano work and retained a rigorous logical thinking of music. Thus, this tragic and narrative piano work was regarded as a pioneer at that time. It was widely praised after Mr. Wang Lisan had performed at the new works concert held at Shanghai Conservatory of Music in the 1950s and then became a formal program at his concert. Later, it was widespread and performed by pianists Zhou Guangren and Ni Hongjin in Berlin and Moscow respectively. Pianist Wu Leyi made a record based on this piano piece and the music score was listed in Piano Works published by both China and the Soviet Union. In 1954, Szabolesi Bence, a Hungarian famous musician, paid a visit to Shanghai and thought highly of this work after appreciating Mr. Wang Lisan' s performance at a symposium. Szabolesi regarded it as a "a work of genius”. Based on inheriting and promoting traditional Chinese music, Mr. Wang Lisan boldly absorbed all kinds of music forms and performance methods in Western European, and developed a new form of exploration.

Sonatina, created by Mr. Wang Lisan in 1957, won the first prize at the piano creation contest organized by Shanghai Conservatory of Music. This work embodied more modernity than other works and had distinct nationality and individuality. Mr. Wang Lisan's polyphony teacher Alzamanov, who was an expert in the Soviet Union, thought that this work was perfect. After being awarded, Mr. Wang Lisan was invited by Shanghai Broadcasting Station to make a record and Shanghai Music Publishing House planned to publish this record. In the late 1970s and early 1980s, music creation in China ushered a new era with the reform and opening-up policy. Therefore, lots of new concepts, new styles and new creation techniques were brought to the music circle in China, and composers had more chances to refer and select. In this new and diversified era, several piano works created by Mr. Wang Lisan drew much attention because of their distinctive features.

For instance, he created Artistic Inspiration from Kaii Higashiyama in 1979 based on four paintings created by a modern Japanese painter named Kaii Higashiyama. Mr. Wang Lisan integrated these fresh and beautiful pictures, namely Winter Flower, Autumn Clothing in the Woods, Lake and Roaring, into this piano work. Before being published officially, Artistic Inspiration from Kaii Higashiyama was introduced and played by both Western Berlin Radio Station and Munich Radio Station and received widespread praise. It was said that Mr. Kaii Higashiyama once wrote to Mr. Wang Lisan in order to extend his sincere gratitude for Mr. Wang Lisan' $\mathrm{s}$ thorough understanding of his works. Among these four parts, Roaring was novel and the most important one, reflecting the composer's spirit of exploration. It was first performed at the 7th Harbin Summer Music Concert in 1979 and won the first prize of “the 4th National Music Works Awards" in 1985.

Mr. Wang Lisan had applied the pentatonic twelve-tone to create music works and made them logical in the context of an open and free atmosphere since the 1980s. Although he inherited traditional excellent music culture both in China and western countries, he avoided being bothered by old thinking model. He distinguished his works from western atonal music and serial music though applying the technical language of the twelve-tone. In addition, he endowed the twelve-tone series of sound with pentatonic features and abundant tonality, but he showed an essential difference between his works and tonal music functional logic. During this period, he created A 
Dream of Heaven and Qin Wang Yin Jiu based on the same poetic names written by poet Li He in Tang Dynasty. In these works, Mr. Wang Lisan, different from his former works no matter in music style, creation idea or aesthetics, integrated the western twelve-tone serial technique into traditional Chinese tone, which embodied a kind of fantastic sense of time and space. This was also a big breakthrough for his art practice and made his works more mature and distinctive.

In the early 1980s, Mr. Wang Lisan created a piano work named Tashanji_—Five Piano Works of Prelude and Fugue. Paying much attention to the oriental national culture and literati complex that this story reflected, this piano work was a set of programmatic polyphony music and made people comprehend a kind of extensive oriental taste and deterrent power produced by the integration of national culture and spirit.

Mr. Wang Lisan's creation of piano music can be divided into two parts: one is non-divertimento structure like Lan Huahua; the other is divertimento structure like Tashanji. Lan Huahua belongs to non-divertimento structure_- theme variation form, but Mr. Wang Lisan, rather than applying western variations mechanically, changed original melody based on the contents narrated by folk songs. The birth of each excellent music works lies in specific social and historical environment and will be affected by such factors as age, nation, class, cultural education and tradition, and customs. Mr. Wang Lisan developed an open thought and a new music concept on account of his solid composing techniques and dense traditional cultural deposits, and sought a progressive road between respecting and breaking through the tradition.

\section{Music Educator}

In the end of 1962, Mr. Wang Lisan was picked off the label "the Rightist" and transferred to the Music Department of Harbin Academy of Arts as a teacher, mainly teaching such courses as composition and polyphonic music. He had begun his teaching career since then. At that time, he was a beloved and respectable teacher because of his profound knowledge and enthusiastic teaching attitude. In 1979, he was promoted to associate professor and held the post of the dean of Academy of Arts at Harbin Normal University in 1985. In 1986, he was promoted to be a professor. He organized other teachers to compile teaching program and textbooks and created as well as improved the modern teach mode of normal colleges, thus cultivating lots of qualified graduates and making the Academy of Arts at Harbin Normal University play an important role in the development of the three northeast provinces of China. Mr. Wang Lisan made great contributions to the higher music education in the northern part of China.

The first half of the 1960s was a prosperous period for the music culture development of Harbin and Mr. Wang Lisan, as a composer, played a key part in this period. After being transferred to Harbin, He created numerous music works for "Harbin Summer Music Concert", which was initiated in 1961 and mainly required new and original works. These works included all kinds of forms such as ensemble of traditional instruments, piano solo and concerto. His performance of orchestra quintet Five Colors Earth was a big success in Shenyang Music Week; and composer Chen Peixun performed orchestral music based on Mr. Wang Lisan's piano work Song of Guerrilla in the 25th Harbin Music Concert. All these distinctive works embodied Mr. Wang Lisan's talent of creation and promoted the development of the northern part of China.

Papers and articles published or read by Mr. Wang Lisan had played a significant role in the music circle of China since the 1980s, such as The Author's Words on "Dream of Heaven”, Speech at National Symphony Music Creation Forum, and his famous paper New Fashion and Old Tradition. These academic articles reflected that Mr. Wang Lisan chose a road that combined modern culture with national tradition in respect of creation.

\section{Music Social Activist}

Mr. Wang Lisan took an active apart in various music activities nationwide. In 1979, he participated in the Fourth Congress of Chinese Literature and Artistic Workers and was appointed as 
a member of council in the Third Congress of Chinese Musicians Association; in 1983, he served as a judge at National Symphony Creation Contest and was appointed as the chairman of Heilongjiang Musicians Association at the same year; in June, 1986, he went to Hong Kong to attend the First Contemporary Chinese Composers Festival as the deputy head of delegation of Chinese Musician Association and was awarded Heilongjiang model worker. In 1987, he was invited to attend a cultural exchange forum held in Stuttgart of the Federal Republic of Germany and taking Foreign Countries_-Western Fantasy as the theme; in 1988, he flew to New York, America, for participating in Cross-Strait Composer Forum. He then was appointed as an executive member of Chinses Musician Association due to his outstanding achievements and as vice chairman of Heilongjiang CFLAC at the same year; and in 1990, he attended the Fourth International Seminar of New History of Chinese Music held by Asian Research Center, University of Hong Kong, with his paper Retrospect of Several Theories and Practices Related to Modern Chinese Music and Chinese Features.

The reason why the author researches Mr. Wang Lisan's life and his piano creation is composed of two parts: on the one hand, as a great contributor to modern Chinese music creation, he himself was a combination of contradiction and conflict as well as confusion and exploration. Mr. Wang Lisan, as a victim of the unjust case of contemporary Chinese musician in the 20th century, suffered hardship that all Chinese intellectuals underwent and his life was a tortuous journey, which was the epitome of all Chinese intellectual and composers. Therefore, people should pay more attention to him as well as his life. On the other hand, People can see his suffering and destiny, mentality and personality as well as exploration and contribution through his inner world, a world that maintained close ties with his music works. Researching on Mr. Wang Lisan's life and his music works, from the perspective of Chinese social ideology and music style evolution in the 20th century, are of great importance in the development of modern Chinese music creation.

Creation of modern Chinese music has been prosperous since the 1980s and with the development of science and technology as well as the enhancement of cultural exchange between east and west, lots of composers and scholars start to focus on how to explain and embody traditional Chinese culture in music creation, how to maintain and promote the unique charm of Chinese culture, and how to combine traditional national music with modern western music techniques. Mr. Wang Lisan's creation reflected his exploration of artistry, creativity, nationality and internationality, and he set an example for modern Chinese music by means of the full-bodied national spirit, rigorous logical thinking, distinctive artistry and modern technical language expressed in his music works. Therefore, researching Mr. Wang Lisan’s music works systematically has certain theoretical significance for the development of modern Chinese music creation and the construction of theoretical science.

\section{Conclusion}

More and more scholars both at home and abroad focus on researching Mr. Wang Lisan's music works and various papers come forth one after another. Formation and Development of Chinese Piano Culture, written by Bian Meng, for example, analyzed Mr. Wang Lisan's piano work Sonatina; Formation and Development of polyphony Thought in Chinese Music, written by Zhu Shirui, studied Mr. Wang Lishan's Tashanji; and other papers written by Wang Yuhe, Wei Tingge, Pufang, Wang Wenjun and so on. All of these papers generalized and analyzed Mr. Wang Lisan's piano works in general. These papers, however, have the following three features: first, the scope of these papers is narrow, mainly focusing on Mr. Wang Lisan's piano works; second, scholars tend to discuss music techniques while rarely focus on the artistic connotation, aesthetic ideal, historical environment and social function that these music works contained; third, research on creation techniques in these papers only focuses on a certain work or some certain aspect of a certain work and from the author's perspective, scholars should make more deep and systematic research.

In the development of modern Chinese music, music works that possess eternal vitality must have a close connection with their corresponding cultural atmosphere, spiritual connotation and 
characteristics of the times, and messages as well as imprints of the age will be reflected due to the frequent usage of western creation techniques and traditional national music, and the promotion of subjectivity and individuality. Therefore, Mr. Wang Lisan's music creation is representative in modern Chinese music and embodies a process from exclusiveness to openness. This paper, through researching Mr. Wang Lisan' s music style, creation concept and aesthetic ideal, provides reference for the development of modern Chinese music culture.

\section{References}

[1] B. Ke, "The Piano Works of Wang Lisan and Seeking of Culture Values," in Art Review, vol. 3, 2013.

[2] S. Liao, “The Disscussion of Wang Lisan,” in People’s Music, vol. 10, 1986.

[3] F. Pu, “A Disscussion of Piano Composition of Wang Lisan,” in Art of Music, vol. 1, 1989.

[4] L. Su, “The Interview of Wang Lisan,” in Piano Artistry, vol. 1, 1998.

[5] L. Wang, "Fashion and Tradition,” in Musicology in China, vol. 3, 1986.

[6] L. Wang, “Tone, Tune Trope, and Others,” Center of Asian Study in University of Hong Kong, 1991..

[7] S. Wan, "Seeking the Beauty of Harmonious Music from Wang Lisan," in Sichuan Drama, vol. 12, 2014.

[8] T. Wei, “The Piano Composition of Wang Lisan,” in People’s Music, vol. 10, 1986.

[9] Y. Zhou, “Commemorate Wang Lisan,” in Contemporary Music, vol. 1, 2016. 